\title{
Family Counseling Anticipating Bullying Behavior In Children
}

\author{
Azmatul Khairiah Sari ${ }^{1}$, Neviyarni ${ }^{2}{ }^{2}$, Yarmis Syukur ${ }^{3}$ \\ 1 STIT Ahlusunnah Bukittinggi, Indonesia \\ 2 Universitas Negeri padang, Indonesia \\ 3 Universitas Negeri padang, Indonesia
}

Corresponding Author azmatulkhairiah998@gmail.com

\begin{tabular}{|c|c|}
\hline \multirow{9}{*}{$\begin{array}{l}\text { ARTICLE } \\
\text { INFO } \\
\text { Article history: } \\
\text { Received } \\
\text { 01 Juni } 2021 \\
\text { Revised } \\
\text { 21 Juni } 2021 \\
\text { Accepted } \\
\text { 03 Juli } 2021\end{array}$} & ABSTRACT \\
\hline & \multirow{8}{*}{$\begin{array}{l}\text { Family counseling is an important thing for a counselor to do. Many } \\
\text { benefits will be obtained by a counselor from providing family } \\
\text { counseling. Family counseling which is the provision of services in the } \\
\text { form of a system will also touch the client to the child. The rise of } \\
\text { bullying cases that occur in children causes counselors and parents to } \\
\text { anticipate in advance so that children do not become perpetrators or } \\
\text { victims of bullying behavior. From bullying behavior, children who } \\
\text { become victims will become low self-esteem, isolate themselves from } \\
\text { social and many other negative impacts that can be caused. Therefore, } \\
\text { family counseling is one of the solutions to prevent bullying from } \\
\text { happening to children }\end{array}$} \\
\hline & \\
\hline & \\
\hline & \\
\hline & \\
\hline & \\
\hline & \\
\hline & \\
\hline \multirow[t]{2}{*}{ Key Word } & Family Counselling, Bullying, Children \\
\hline & Azmatul Khairiah Sari ${ }^{1}$, Neviyarni $S^{2}$, Yarmis Syukur ${ }^{3}$ (2021). Family \\
\hline \multirow[t]{2}{*}{ How to cite } & \\
\hline & \\
\hline
\end{tabular}

\section{INTRODUCTION}

Bullying is a phenomenon all around us. Bullying itself is not something new we hear. This is a problem that becomes a global issue that must be resolved. Bullying has occurred in many countries and in Indonesia itself has become something that is usually done by someone who has "power" or power. The power he has is used as something negative, namely oppressing others.

Bullying is a deliberate aggressive behavior to show the strength that he has and give a disturbance in the form of physical and psychological disorders. This disorder is carried out on those around him who are weak and do not have the ability to fight back. Bullying that occurs will have a negative impact not only on the victim but also for the perpetrator.

In Indonesia itself there are also cases of bullying. One of the agencies or institutions that releases the results of bullying cases in Indonesia is the Indonesian Child Protection Commission (KPAI). KPAI noted that there were 253 cases of bullying from 2011 to 2016 (Nuridha, 2017). Then KPAI released data on bullying cases from July to May 2018 there were 36 cases of bullying, which if presented was $22.4 \%$ of the 161 cases recorded in the education sector (Nurlita \& Widiastuti, 2018). 
From the case released by KPAI, it can be seen that bullying is increasing every year. And this is a matter of great concern. Whereas at the level of children themselves, they have a legal umbrella so that they are protected from the threats that surround them. a worrying general phenomenon.

Children will have time to gain knowledge at school. However, one of the things that is difficult to contain at school is the tendency of children to engage in bullying behavior (Mujiati, 2015). Children who are in school should be away from bullying behavior, whether they are victims or perpetrators of bullying. As stated in the 1945 Constitution article 28B (paragraph 2): "Every child has the right to survival, growth and development, and the right to protection from violence and discrimination". Child Protection Law No. 23 of 2002 Article 54 also states that: "Children in and within the school environment must be protected from acts of violence committed by teachers, school administrators, or their friends in the school concerned, or educational institutions. other".

Bullying is considered a cause of health problems for children who are at primary school age. They will deal with adjustment problems including mental health and violent behavior (Kusuma, 2016). So bullying is something that causes a child to find it difficult to enjoy playing and learning if he becomes a victim or perpetrator in bullying behavior. Therefore, this behavior must be anticipated early on.

The main factors of bullying by students are personality factors, family factors, childhood experience factors and school environmental factors (Muhopilah, et al. 2019). In addition, other opinions state that the factors that influence bullying behavior are: (a) childhood experience (b) lack of attention from parents, (c) support from peers, (d) personality factors of the perpetrator (Mujtahidah, 2018). The cause of bullying behavior in schools is because children who have not been properly prepared by their families not to behave in school bullying and deal with bullying appropriately.

One way to anticipate children from bullying behavior is from their own families and through help from family counseling. Where families are trained how they can anticipate their children from bullying behavior, whether they are perpetrators or victims of bullying behavior.

\section{RESEARCH METHODE}

This article is a qualitative research. This type of article is included in the category of library research. Data collection techniques by reviewing books, literature, notes, and various reports related to the problem to be solved. bibliography is more than just serving the functions mentioned to obtain research data. Strictly speaking, library research limits its activities only to library collection materials without requiring field research (Zed, 2018: 1-2).

In this paper, it is more focused on discussing how families through family counseling can anticipate bullying behavior in their children who are in school. Anticipating being victims and perpetrators of bullying. In addition, schools are one of the places where bullying occurs. 


\section{RESULT AND DISCUSSION}

\section{Bullying Behavior}

Bullying is a loan word from English. Bullying comes from the word bully which means a bully, or someone who annoys weak people. Psychologically, bullying is a facial expression that is demeaning, rude or disrespectful, humiliating and ostracizing. The American Psychological Association (2013) defines bullying as: "A form of aggressive behavior in which someone intentionally and repeatedly causes another person injury or discomfort. Bullying can take the form of physical contact, words or more subtle actions"

Meanwhile, according to Coloroso (2003) that bullying is a hostile act that is carried out consciously and intentionally which aims to hurt such as scaring through threats of aggression and causing terror, including actions that are planned or spontaneous, real or almost invisible in front of someone.

Bullying is an act that abuses power/power to oppress people who they think are weak and powerless. The most common form of bullying at school is verbal abuse, which can come in the form of teasing, teasing or teasing someone. Cases of bullying that were initially only verbal can also lead to more dangerous treatments, such as physical abuse such as pushing, kicking, slapping, hitting.

Bullying behavior does not have to be through words alone. But it can be indirectly. Bullying can be seen directly with physical or verbal attacks or social isolation. Kicking, punching friends, pushing, naming bad names and many more physical attacks that can be carried out by bullies. The attitude of inviting friends to stay away from someone who is in class because he is poor or not smart is also an attitude of bullying. This bullying attitude creates its own trauma to the victim. Meanwhile, indirect bullying is for example spreading malicious rumors or damaging property, including cyberbullying or electronic bullying.

And Olweus (1997) formulated the characteristics of bullies as follows: (1). Forces that force to dominate and subjugate other students to get what they want, (2). Follow your heart and get angry easily, (3). Shows little empathy or concern for students who are victims, (4) Often challenging and aggressive towards adults including parents and teachers, (5). Often gets carried away in antisocial behavior towards others or is accustomed to activities such as vandalism, delinquency and drug use, (6). If they are boys they are usually physically stronger than other boys and especially their victims. So the perpetrator of the bullying will try to conquer the social with the power he has. With his strength he tries to subdue other students to do what the bullies want.

Bullies usually have a temper and do not have empathy for their friends. Bullies will oppose parents and teachers if they are reprimanded. And in general, bullies will show their strength in the form of physical suppression to their friends.

Bullies do this act of hurting other people consciously and on the initiative, without any provocation from the victim. Victims of bullying can be individuals or groups (Careera, DePalma, \& Lamerias, 2011). For perpetrators, bullying can lead to 
decreased empathy (Wilford, Bouton, Banks, Bender, Dieterich \& Jenson, 2015), increased aggressive behavior (Evans, Smokowski, Rose, Mercado, \& Marshal, 2018), accustomed to getting things by force (Hawley , 2003), increased anti-social behavior (Farington \& Ttofi, 2011), disliked by friends so that it can lead to negative feelings about the future (Bruyn, Cillessen, \& Wissink, 2010), and the potential for mental health problems (Healy, Sanders, \& Lyer, 2015). Lack of empathy for bullies and prevention by schools causes bullying to occur in schools (Rahayu, 2019).

It is unfortunate if children become part of the perpetrators of bullying because of the many negative impacts they will get. Bullies do not have empathy because they feel great after bullying their friends. With low empathy, of course, the aggressive attitude of the perpetrator will increase and he will have anti-social behavior because he does not feel close to his friends. And furthermore, the bully will ruin his future and he can have unhealthy mental health.

Bullying is part of aggressive behavior that can damage a person's future and is carried out intentionally and consciously and repeatedly on the same victim to harm and persecute the victim accompanied by an imbalance of power between the perpetrator and the victim of the bullying.

Bullying can be classified as aggressive behavior that is very destructive to a person's future which is done intentionally/consciously and repeatedly with the aim of harming the victim and can be accompanied by a difference or imbalance of power between the perpetrator and the victim. Children who are physically bigger are generally one of the characteristics of bullies (Latifah, 2012). And the victims of bullying are children who are physically smaller. This very clear difference between large and small physical is considered to be a trigger for bullying behavior. Children who are big will feel free to suppress children who are small.

A school requires prevention and intervention programs against bullying cases because:

a. Bullying behavior seriously affects the emotional, physical, and academic achievement of students who are victims of bullying

b. Bullying behavior can make the learning and teaching process uncomfortable and unsafe at school (Yusuf, et al, 2012).

Then the counselor at the school must seek the occurrence of a family counseling for the student's family to anticipate the widespread bullying behavior.

\section{Family Counseling}

According to Golden and Sherwood (in Latipun, 2001) family counseling is a method designed and focused on family problems in an effort to help solve the client's personal problems. In general, the problems experienced are personal problems because the client experiences it himself. However, the counselor considers the personal problems experienced are problems that will damage the system in a family. Therefore, family assistance is needed in overcoming these problems.

Family counseling is an effort of assistance given to individual family members through the family system (improvement of family communication) so that their 
potential develops as optimally as possible and the problem can be overcome on the basis of the willingness to help from all family members based on their willingness and love for the family (Willis, 2008). In family counseling, communication is expected to occur between family members so that the expected family harmony can be achieved.

The purpose of family counseling in general is according to Glick and Kessler (in Latipun, 2001) is to facilitate the communication of thoughts and feelings between family members, change the disorder and inflexibility of roles and conditions, provide services as models and education of certain roles that are shown to family members. In addition, in general, family counseling according to Willis (2008) is to help family members learn and appreciate emotionally that family dynamics are links between family members, to help family members become aware of the fact that if one family member has a problem, it will affect the perceptions, expectations, and interactions of other members, in order to achieve a balance that will make the growth and improvement of each member, to develop full appreciation as a result of the parental relationship.

In particular, Willis (2008) reveals that family harmony aims to increase tolerance and encouragement of family members to idiosyncratic ways or the advantages of other members, to develop tolerance for family members who experience frustration or disappointment, conflict, and sadness that occurs due to factors in the family system or outside the family system, developing motives and potentials, each family member by encouraging (supporting), encouraging, and reminding the member, developing the success of parents' self-perception realistically and with the other members.

\section{Family Counseling in Anticipating Bullying Behavior in Children}

Family counseling is something that must be done by counselors in anticipating the spread of bullying behavior. As discussed earlier, the factors that cause bullying behavior are family and past experiences. Because the family is the cause of bullying behavior, of course the family can prevent bullying behavior in their children.

The family is the beginning of a child's development so that the family plays a very important role in making his child into an individual who is smart, healthy and has good social adjustments (Maskanah, 2017). Children who are used to being undisciplined at home will be difficult to manage at school and if they are raised with unclear rules, they will tend to rebel at school (Waruwu, 2010). Differences in parenting patterns in each family will make different behavior among students at school and schools will have difficulty forming children if they are not assisted by their families (Mahfuzh, 2009).

So counselors can try to anticipate bullying behavior through family counseling because the family is a forum for forming and changing children's behavior. With family counseling, it is hoped that children can change bullying behavior and no longer become bullies. In addition, children are ready for bullying behavior by their friends and they can act on bullying behavior by their friends against them. 
In addition, the counselor will strive so that the family he provides counseling services can change their child's bullying behavior or anticipate bullying behavior. There are several things that are considered in family counseling to anticipate bullying behavior (Lubis, 2011), including;

a. Prepare family members. The counselor must seek approval from the client who is his family member, and who can be involved in the family counseling process. This needs to be done because not all family members are aware of the problem. For example, the father does not know that his son is a bully at school, and he is afraid that something undesirable will happen in his family. So ask for approval first if it's okay for his father to be involved, and if it's possible to where he can only know the problem. Counselors must apply the principle of confidentiality so that family counseling can run well and clients can participate in the family counseling process voluntarily.

b. Creating allies. The counselor must explore the client's problems and understand the client. So the counselor must involve family members who can be used as allies and are invited to work together in solving client problems. If the client is asked to stop bullying behavior, the family who is used as an ally by the counselor also helps from home.

c. Use fear/threat appropriately. If there are family members who do not agree with the implementation of counseling to be carried out by the counselor, the counselor can provide a logical reason why it is important for family counseling. And also important to tell what underlies bullying behavior is not recommended to be left alone.

There are seven steps in family counseling that can be applied by counselors to perpetrators or victims of bullying, including:

a. Respond to emergencies. In this case the counselor is expected to be able to provide calm and show a willingness to provide family counseling to clients. Clients who may feel guilty about their behavior that has bullied their friends, the counselor must show seriousness to the client. Or clients who are victims of bullying ask for help from a counselor, then the counselor must show seriousness in providing family counseling.

b. Focus on family members. It could be that in the process of deepening the client's problem, the counselor understands that the cause of bullying behavior is one of his family members. So the counselor must see that the problem of bullying faced by the child is a problem for all family members as well and must work together to solve it.

c. Define the crisis. The counselor must know the source of the crisis or problem the client is facing. And this problem will be a problem shared by other family members.

d. Calming family members. Counselors can make preliminary conclusions about the problems experienced by clients. The counselor is expected to reassure family members who may be surprised by his child's behavior. 
Mothers who are shocked by her child's confession that she is a bully at school, the counselor must be able to calm the mother because it could damage the family counseling atmosphere that will be held if the mother cries and intends to go home immediately.

e. Suggest changes. Counselors provide advice and direction that can help family members decide what changes to make in the family. If their child becomes a bully, the counselor can suggest changing communication patterns at home. In addition, there are also many ways that family members can do so that their children can change bullying behavior.

f. Facing the attitude of resisting change. After the counselor tells the family to make changes, the counselor must quickly find out which family members agree with the change. Or who are family members who refuse to change behavior patterns at home. The counselor must provide an understanding that the change is something that must be achieved.

g. Stop counseling. After progress is made during the family counseling process, family members can be invited to work together, each family member has come out of a crisis period, then counseling can be ended. If the child is able to understand that bullying behavior is dangerous and can cost him/herself, then the counseling can be ended.

Counselors must apply the steps in family counseling well and understand each of these steps as an effort that can be done in stopping bullying cases.

\section{CONCLUSION}

Cases of bullying that are rampant in society do not only occur in adults, but also occur in children. This bullying case if left unchecked will make children feel depressed and have no self-confidence. Meanwhile, the bullies will make the child feel guilty and in the end he will feel guilty and furthermore will be depressed by what he has done. Therefore, one thing that can be done is to improve patterns in the family and this can be done through family counseling. Family counseling can indirectly be a solution in anticipating bullying behavior to continue.

\section{REFERENCES}

Bruyn, E. H., Cillessen, A. H. N., \& Wissink, I. B. (2010). Associations Of Peer Acceptance And Perceived Popularity With Bullying And Victimization In Early Adolescence. The Journal of Early Adolescence, 3, 543-566. https://doi.org/10.1177/0272431609340517

Careera, V. M., DePalma, R., \& Lamerias, M. (2011). Toward A More Comprehensive Understanding Bullying In School Setting. Educational Psychology Review, 23(4), 479-499. http:/ / dx.doi.org/10.1007/s10648-011-9171-x

Coloroso, B. 2003. The Bully. The Bullied, and The Bystander: Fom Preschool To High School-How Parents and Teachers Can Help Break The Cycle of Violence. New York: Harper Resource 
Evans, C. B. R., Smokowski, P. R., Rose, R. A., Mercado, M. C., \& Marshal, K. J. (2018). Cumulative Bullying Experiences, Adolescent Behavioral And Mental Health, And Academic Achievement: An Integrative Model Of Perpetration, Victimization, And Bystander Behavior. Journal of Child and Family Studies, 1-14. Doi: 10.1007/s10826-018-1078-4.

Farrington, D. P., \& Ttofi, M. (2011). Bullying as a predictor of offending, violence, and later life outcomes. Criminal Behaviour and Mental Health, 21(2), 90-98. https://doi.org/10.1002/cbm.801

Hawley, P. H. (2003). Prosocial And Coercive Configurations Ofresource Control In Early Adolescence: A Case For The Well-Adaptedmachiavellian. Merrill-Palmer Quarterly, 49(3), 279- 309.https:// doi.org/10.1353/mpq.2003.0013.

Healy, K. L., Sanders, M. R., \& Lyer, A. (2015). Parenting Practices, Children's Peer Relationships And Being Bullied At School. Journal of Child and Family Study, 24, 127-140, Doi: 10.1007/s10826- 013-9820-4

Kusuma, M. P. (2016) Perilaku School Bullying Pada Siswa Sekolah Dasar Negeri Delegan 2, Dinginan, Sumberharjo, Prambanan, Sleman, Yogyakarta. Universitas Negeri Yogyakarta

Latifah, F. (2012). Hubungan Karakteristik Anak Usia Sekolah Dengan Kejadian Bullying Di Sekolah Dasar X Di Bogor (Skripsi tidak dipublikasikan). Fakultas Ilmu Keperawatan Universitas Indonesia, Depok

Latipun. (2001). Psikologi Konseling. Malang: UMM Press.

Lubis, Namora Lumongga. 2011. Memahami Dasar-Dasar Konseling dalam Teori dan Praktek. Jakarta: Kencana.

Mahfuzh, Syekh Jamaluddin. 2009. Psikologi Anak dan Remaja Muslim. Jakarta: Putra Alkautsar

Maskanah, Khusnul. Hubungan Keharmonisan Keluarga Dengan Perilaku Bullying Ditinjau Dari Status Ekonomi Orang Tua Siswa Di SMP N 5 Sleman. E-Journal Bimbingan dan Konseling Edisi 2 Tahun ke-6 2017

Muhopilah, Pipih \& Fatwa Tentama. Faktor-faktor yang mempengaruhi perilaku bullying. Jurnal Psikologi Terapan dan Pendidikan ISSN: 2715-2456 Vol. 1, No. 2, November 2019, pp. 99-107

Mujiati, 2015. Peningkatan Self Esteem Siswa Korban Bullying melalui Teknik Assertive Learning. Jurnal Fokus Konseling, (Online), 1 (1). Diperoleh dari http://ejournal.stkipmpringsewu-lpg.ac.id/index.php/fokus

Mujtahidah. Analisis Perilaku Pelaku Bullying dan Upaya Penanganannya (Studi Kasus Pada Siswa MAN 1 Barru). Indonesian Journal of Educational Science (IJES). Volume 1, No 1 September 2018. ISSN 2622-6197

Nuridha, L. (2017, November 3). Kasus bullying meningkat, perilaku di dominasi oleh remaja. https://kumparan.com/@kumparanstyle/kasus-bullying-meningkatpelaku-didominasi-olehremaja. 
Nurlita, D., \& Widiastuti, R. (2018, July 23). Hari anak nasional, KPAI catat kasus bullying paling banyak. https://nasional.tempo.co/read/1109584/hari-anaknasional-kpai-catat-kasus-bullyingpaling-banyak

Rahayu, Bety Agustina, Iman Permana. Bullying Di Sekolah : Kurangnya Empati Pelaku Bullying Dan Pencegahan. Jurnal Keperawatan Jiwa Volume 7 No 3, Hal 237 - 246, November 2019 ISSN2338-2090 (Cetak) FIKKes Universitas Muhammadiyah Semarang bekerjasama dengan PPNI Jawa Tengah ISSN 2655-8106 (Online)

Olweus, D. 2004. Bullying At School: Prevalence Estimation, A Useful Evaluation Design, and A New National Initiative In Norway. Assosiation for Child Psychology and Psychiatry Occasional Papers (23), 5-17

Undang-Undang No.23 Tahun 2002. Tentang Pelindungan Anak. Jakarta: Visimedia Waruwu, Adelise. 2010. Membangun Budaya Berbasis Nilai. Yogyakarta: Kanisius.

Wilford, A., Bouton, A. J., Bank, S. S. F., Bender, K. A., Dieterich, W. A., \& Jenson, J. M. (2015). The effect of bullying and victimization on cognitive empathy development during the transition to middle school. Child youth care forum. Doi: 10.1007/s10566015-9343-9.

Willis, S (2008). Konseling Keluarga (Family Counseling). Bandung: Alfabeta

Yusuf, Husmiati \& Adi Fahrudin. Perilaku Bullying: Asesmen Multidimensi Dan Intervensi Sosial. Jurnal Psikologi Undip Vol. 11, No.2, Oktober 2012 